\title{
Review of Economic pluralism, edited by Robert Garnett, Erik Olsen, and Martha Starr. London: Routledge, 2009, 336 pp.
}

\author{
IRENE VAN STAVEREN
}

ISS, Erasmus University Rotterdam

This volume brings together in twenty accessible chapters a large number of authors contributing previously unpublished work on economic pluralism. The editors present it as the collection of economic pluralism for the twenty first century. This sounds very ambitious but the table of contents is promising, because it reflects pluralism in themes and approaches as well as diversity in authors' geographical origin and gender. In this review, I will try to assess to what extent the contents of the book also reflect this wide diversity.

The introduction to the volume by the three editors distinguishes first-wave and second-wave pluralists. Garnett, Olsen, and Starr characterize first-wave pluralists in terms of paradigmatic selfsufficiency, striving for an "analytically unified and self-contained school of thought whose practitioners need not engage in scholarly dialogue beyond the boundaries of their own tradition" (p. 4). Secondwave pluralists, in contrast, aspire to a pluralism derived from John Stuart Mill's arguments against the tyranny of the majority in On liberty; as the editors put it, "a positive valuing of a diversity of views in the minimal sense that one who is so committed would not want to reduce the number of available narratives or views" (p. 4.). This is formulated more simply by Tony Lawson in chapter seven, as "the affirmation, acceptance, and encouragement of diversity" (p. 99). Economic pluralism presents an overview of second-wave pluralism in three parts. The first set of chapters discusses the philosophical realms of epistemology, ontology, and methodology, whereas the second set of chapters goes on to real-world economies, and the third part discusses economics education.

The first chapter, written by Fred Lee, makes the case for secondwave pluralism by showing how different schools of thought have engaged with each other recently. He provides an insightful table with examples of publications at the cross roads of different heterodox traditions, such as post Keynesianism and feminist economics, or 
institutionalism and social economics. William Waller, in the third chapter, makes the same argument, but, like Lee, focuses on heterodox schools of thought rather than neoclassical or mainstream economics. The second chapter, by David Colander, makes a very different point. It proposes an 'inside the mainstream' strategy for heterodox economists in order to further the cause of economic pluralism beyond the relatively small group of heterodox economists. His argument is strategic. Colander pleas for training heterodox students to a high level in the quantitative skills of mainstream economics because "the only ones who are allowed to break the rules are those who have demonstrated a full command of them" (p. 41). I find both viewpoints appealing: Lee's and Waller's appeal for continued, and increased, mutual engagement between various heterodox traditions, and Colander's appeal for engagement between heterodox schools and the mainstream. Of course, the one position does not exclude the other, but second-wave pluralism would benefit, in my view, from a combination of the two, so that mutual engagement between a particular heterodox school of thought and a mainstream school would also be encouraged. And here we can also find successful examples in the literature, for instance between feminist and experimental economics, or between institutional and behavioural economics.

The fourth chapter, by Strassmann, Starr, and Grown brings a very different issue to the pluralist table. The authors argue convincingly that heterodox pluralists focus too much on diversity in theoretical and methodological approaches and too little on economic problems concerning the improvement of human lives, which requires a focus on gender, class, and race. They point to Geoffrey Hodgson as an example of a heterodox author who tends to ignore gender diversity, quoting only 16 women in a book containing more than thousand citations, and contrast this with Amartya Sen as an example of a pluralist economist who has always taken a gender perspective on board.

Chapter five, by Marqués and Weisman, takes us into the philosophy of science and considers the relevance of Thomas Kuhn's work for pluralism in economics. They argue that Mill's fallibilism is a more suitable foundation for pluralism than Kuhn's incommensurability thesis. Furthermore, they find Kuhn's philosophy corrosive of pluralism because "those who believe in incommensurability (even in its weaker sense) will lack the incentives for engaging in a conversation with 'foreign' positions” (p. 78). The authors strengthen their point by noting 
that although truth matters, knowledge is key for pluralism, because knowledge requires a clear perception of the motives and reasons which give rise to the idea one takes as true. In other words, they make a clear case for second-wave pluralism as openness and engagement with diversity.

The second part of the book focuses on real-world economies, starting off with a chapter by Greenwood and Holt arguing that development economics should go beyond concern with GDP growth. Although development economics is among the fields that tend to be most open to pluralism, because of its real-world orientation, there are still pleas for monism around. For example, in an influential recent paper Angus Deaton (2010) defends, in a strikingly positivist manner, deductive hypothesis testing as the appropriate method for development economics. Other chapters in the section discuss themes like equity, capitalism, and local exchange networks.

The third and final part of the book deals with economics education. This part is kicked-off by McGoldrick who emphasizes non-lecture based pedagogical practices. I fully support this approach to pluralist economics teaching, as it is foundational for getting across second-wave pluralism as really engaging with pluralism in methodology, theory, themes, and policy recommendations-a good example of pluralist economics education is presented by Jack Reardon (2009) in his edited volume on how to make economics teaching pluralist. An important methodological point is made by Butler, who argues that economics teaching should go beyond the false dichotomy of positive/normative economics. This is precisely what only very few textbooks and handbooks do, even those coming from heterodox schools of thought.

The final chapter, twenty, by Varoufakis, provides an interesting overview and self-assessment of a pluralist doctoral programme at the University of Athens. But this chapter should not have been placed at the end of the volume because it undermines one of second-wave pluralism's objectives, namely an open, unprejudiced engagement with any school of thought, including the neoclassical. The chapter clearly distances itself from neoclassical economics with characterizations of it as "mystification" and "witchcraft". By ending with this chapter, the volume leaves behind the impression that it is a critique of neoclassical economics after all, rather than a plea for second-wave pluralism. 
Moreover, this ending to the volume draws attention to the lack of a closing chapter by the editors. It would have been helpful to see this volume end with a final word on the pluralism of perspectives they have offered to their readers, and on how to really move away from first-wave pluralism-which chapter twenty still resembles-to second-wave pluralism. But apart from this unfortunate ending, I find Economic pluralism a highly recommendable book that points at directions for furthering pluralism in economic methodology, theory, applied economics, and economic education.

\section{REFERENCES}

Deaton, Angus. 2010. Understanding the mechanisms of economic development. Journal of Economic Perspectives, 24 (3): 3-16.

Reardon, Jack (ed.). 2009. The handbook of pluralist economics education. London: Routledge.

Irene van Staveren is professor of pluralist development economics at the Institute for Social Studies (ISS) in The Hague (Erasmus University Rotterdam). Her research interests include the ethics of care, feminist economics, social capital, and the relationship between efficiency and equity. Her recent publications include Ethics and economics (edited with Mark D. White, Routledge, 2009) and The handbook of economics and ethics (edited with Jan Peil, Edward Elgar, 2009).

Contact e-mail: <staveren@iss.nl> 